\title{
Ultrasound-Guided Liver Resection of a Tumor Involving the Hepatocaval Confluence
}

\author{
Alexandru Barcu ${ }^{1,5}$, Cosmin Verdea ${ }^{1}$, Alin Kraft ${ }^{1,2}$, Bogdan Brasoveanu', Dana Tomescu ${ }^{3,4}$, Irinel Popescu ${ }^{1,2}$, \\ Florin Botea ${ }^{12^{*}}$ \\ ${ }^{1}$ Center of General Surgery and Liver Transplantation, Fundeni Clinical Institute, Bucharest, Romania \\ ${ }^{2}$ Faculty of Medicine, Titu Maiorescu University, Bucharest, Romania \\ ${ }^{3}$ Department of Intensive Care and Anesthesiology, Fundeni Clinical Institute, Bucharest, Romania \\ ${ }^{4}$ Carol Davila University of Medicine and Pharmacy, Bucharest, Romania \\ ${ }^{5}$ Medical Doctoral School, IOSUD Titu Maiorescu University of Bucharest, Romania
}

${ }^{*}$ Corresponding author:

Florin Botea, MD

Center of General Surgery and Liver Transplantation

Fundeni Clinical Institute

Faculty of Medicine Titu Maiorescu

University, Bucharest, Romania

E-mail: boteaflorin@yahoo.com

\section{Rezumat}

Rezecția hepatică echoghidată a unei tumori localizate la confluența hepato-cavală

Prezentăm cazul unei paciente în vârstă de 72 de ani, cu multiple comorbidități cardio-vasculare, internată în centrul nostru pentru o tumoră hepatică, imposibil de biopsiat pe cale percutanată. Examenul CT decelează o formațiune tumorală cu aspect radiologic de colangiocarcinom, localizată în segmentul I superior (partea superioară a porțiunii para-cavale şi întregul lob caudat), cu extensie spre segmentele VII, VIII, IV superior şi II, ce invadează vena hepatică dreaptă şi medie, aderentă de vena hepatică stângă şi vena cavă inferioară în porțiunea retrohepatică. Demnă de menționat este existența a 2 vene hepatice drepte inferioare accesorii, care ne-au permis să efectuăm o rezecție echoghidată non-anatomică transversală superioară, a segmentelor I, VII, VIII, IV superior şi II, ce a implicat şi vena hepatică dreaptă şi pe cea medie, cu prezervarea venei hepatice stângi, prin detaşarea tumorii de la acest nivel, dar şi de pe vena cavă inferioară retrohepatică. $\mathrm{Cu}$ toate că, literatură încă dezbate asupra rezecției vasculare $R 1$ pentru colangiocarcinom, am decis să promovăm această abordare asupra venelor hepatice, dar o considerăm proscrisă asupra pediculilor portali, astfel drenajul venos al hemificatului stâng restant a fost asigurat de vena hepatică stângă, iar pentru hemi-ficatul drept restant de venele accesorii. Chiar dacă, rezectia $R 1$ vascular pentru venele hepatice în tumorile localizate la confluența hepato-cavală ce implică toate venele hepatice este 
dificilă din punct de vedere tehnic, o considerăm fezabilă cu precădere atunci când echografia intraoperatorie este utilizată.

Cuvinte cheie: rezecție hepatică, ghidaj ecografic intraoperator, tumoră la confluența hepatocavă, rezecție hepatică transversală superioară, colangiocarcinom intrahepatic

\begin{abstract}
We present the case of a 72-year-old patient with multiple cardiovascular comorbidities, hospitalized in our center for a liver tumor, impossible to biopsy percutaneously. CT examination detected a tumor formation with radiological features of cholangiocarcinoma, located in the upper part of segment I, extending to segments VII, VIII, IV superior and II, invading the right and middle hepatic vein, adherent to the left hepatic vein and to the retrohepatic inferior vena cava. Worth mentioning is the existence of 2 accessory lower right hepatic veins, which allowed us to perform a superior transverse non-anatomical ultrasound resection of the upper I, VII, VIII, IV and II segments, which also involved the right and middle hepatic veins, preserving the left hepatic vein, by detaching the tumor from it, but also from the retrohepatic inferior vena cava. Although the literature still debates the $\mathrm{R} 1$ vascular resection for cholangiocarcinoma, we decided to adopt this approach on the hepatic veins. Of note, we consider this policy not applicable for the portal pedicles. By adopting this strategy, the venous drainage of the remaining left hemiliver was ensured by the hepatic vein, and of the right one by the accessory veins. Although resecting tumors located at the hepato-caval confluence involving all hepatic veins is technically difficult, we consider it feasible especially when intraoperative ultrasound is used.
\end{abstract}

Key words: liver resection, ultrasound guidance, tumor involving the hepatocaval confluence, upper transversal hepatectomy, intrahepatic cholangiocarcinoma

\section{Introduction}

Resection of tumors located at hepatocaval confluence are technically challenging, particularly in insuring the venous drainage of the remnant liver. The present video shows a clinical case that benefitted from such type of resection.

\section{Case Report}

A 72-year-old female patient (BMI 30), with congestive heart failure, atrial fibrillation, hypertension, ischemic heart disease was diagnosed at CT and MRI with a liver tumor with radiological features of cholangiocarcinoma, involving the hepatocaval confluence and in contact with the retrohepatic inferior vena cava (IVC), located in segment 1 (supe- rior part of the paracaval portion and the entire caudate lobe) extending to segments 7 , 8, 4 superior and 2. AFP, CEA, CA19-9 within normal range. Percutaneous biopsy was not considered due to the very difficult approach.

The tumor was invading the right and middle hepatic veins and in contact with the left hepatic vein, but two large accessory inferior right hepatic veins were present. These allowed an upper transversal liver resection (1) consisting in a non-anatomic resection of segments $1,7,8,4$ superior and 2 , resecting the right and middle hepatic vein and preserving the left hepatic vein by detaching the tumor at this level and from the retrohepatic IVC (R1 vascular). Even though accepting $\mathrm{R} 1$ vascular in case of cholangiocarcinoma may be criticized (2), our policy is to 
accept $R 1$ vascular in case of hepatic veins, but not in case of portal pedicles (except in case of otherwise unresectable tumor in contact with the main portal bifurcation). We consider that true $\mathrm{R} 1$ vascular is only in case of hepatic veins, as in case of portal pedicles the tumor is in fact in contact with the glissonean sheath of the portal pedicle (and not with vascular structures), and therefore it carries, in our opinion, a higher risk of tumor infiltration. We did not choose the aggressive surgical alternative of venous resection and reconstruction of the IVC and LHV, as it involved a significantly higher risk of morbidity and mortality in a patient with severe comorbidities and advanced age. Moreover, we did not have a pathological diagnosis at surgery. By accepting R1 vascular for the IVC and left hepatic vein, the venous drainage of the remnant liver was insured by the latter (for the left remnant hemiliver) and the accessory veins (for the right remnant hemiliver). The resection was carried out using a J-shaped incision, with prior complete mobilization of the retrohepatic inferior vena cava and complete detachment of the tumor from the vena cava, that allowed its control by placing tourniquets. During dissection, particular care was payed for preserving the two right inferior accessory veins. Tourniquets were also placed on the right hepatic vein and on the common trunk of the middle and left hepatic veins. Intraoperative ultrasound (IOUS) did not show any other liver lesions. The resection area was marked under IOUS guidance. The liver transection was also carried out under IOUS-guidance (2), using Harmonic ${ }^{\circledR}$ scalpel in the superficial portion (first $2-3 \mathrm{~cm}$ ) and crush clamping technique in the deeper part of the liver.

\section{Results}

On demand intermittent Pringle time was 30 minutes (two periods of 15 minutes with 5 minute interval). There were no intraoperative incidents. Operative time was $440 \mathrm{~min}^{-}$ utes. Blood loss was $1350 \mathrm{ml}$ with no blood trans-fusion. The postoperative course was uneventful, and the patient was discharged in POD 8. At pathology, a G1-G2 pT2 cholangiocarcinoma was diagnosed.

\section{Conclusion}

Resection of tumors at hepatocaval confluence involving all hepatic veins, even though technically demanding is safe, especially when intraoperative ultrasound is used for guidance. Further studies are needed to clarify the difference in terms of oncological outcome for $\mathrm{R} 1$ resection in case of hepatic veins versus portal pedicles.

\section{Acknowledgements}

I want to express my gratitude to Professor Irinel Popescu, my research supervisor, for his guidance and support during this project. This research paper is part of my $\mathrm{PhD}$ thesis "Intraoperative ultrasound in liver resection for colorectal metastases" (Medical Doctoral School, IOSUD Titu Maiorescu University of Bucharest).

\section{References}

1. Torzilli G, Procopio F, Donadon M, Del Fabbro D, Cimino M, Garcia-Etienne CA, et al. Upper transversal hepatectomy. Ann Surg Oncol. 2012; 19(11):3566

2. Torzilli G, Viganò L, Fontana A, Procopio F, Terrone A, Cimino MM, et al. Oncological outcome of R1 vascular margin for mass-forming cholangiocarcinoma. A single center observational cohort analysis. HPB (Oxford). 2020;22(4):570-577.

3. Torzilli G, Montorsi M, Del Fabbro D, Palmisano A, Donadon M, Makuuchi M. Ultrasonographically guided surgical approach to liver tumours involving the hepatic veins close to the caval confluence. Br J Surg. 2006; 93(10):1238-46. 